\title{
Composite-alumina-carbon molecular sieve membranes prepared from novolac resin and boehmite. Part II: Effect of the carbonization temperature on the gas permeation properties
}

\author{
Margot A. Llosa Tanco ${ }^{a, b}$, David A. Pacheco Tanaka ${ }^{a, b,{ }^{*}, \text { Adelio Mendes }}{ }^{a, * *}$ \\ a LEPABE-Faculdade de Engenharia, Universidade do Porto, Rua Dr. Roberto Frias, \\ 4200-465 Porto, Portugal \\ b Tecnalia-Parque Tecnologico de San Sebastión, Paseo Mikeletegi 2, E-20009 Donostia, \\ San Sebastian, Spain
}

\begin{abstract}
The influence of carbonization temperature on the permeation properties and aging of thin $(4 \mu \mathrm{m})$ supported carbon molecular sieve membranes (c-CMSM), prepared from in house synthesized novolac phenolic resin loaded with boehmite nanoparticles, were studied. Just after membrane carbonization (fresh membrane), high permeance to N2 and $\mathrm{O} 2$ and low $\mathrm{O} 2 / \mathrm{N} 2$ permselectivities were observed; the highest permeations were observed for carbonization end temperatures between $500^{\circ} \mathrm{C}$ and $700^{\circ} \mathrm{C}$. After leaving the c-CMSM 1 day in the air, a large decrease in the permeation and considerable increase in the permselectivity were observed due to the reduction of the pore size by oxygen chemisorption and water physical adsorption; the permeability to $\mathrm{H} 2$ and $\mathrm{H} 2 / \mathrm{N} 2$ ideal permselectivity for a mem- brane carbonized at $550{ }^{\circ} \mathrm{C}$ are close to palladium membranes for low temperature $\left(<100^{\circ} \mathrm{C}\right)$. The effect of the permeation characteristics of the membranes carbonized at various temperatures and the removal of water adsorbed in the pores by heat treatment were studied.
\end{abstract}

\section{Introduction}

The growing demand for efficient and "clean" energy has resulted in an increased global acceptance of the so-called "hydrogen economy" as a potential long 2 term solution to the growing energy crisis [1]. Hydrogen is used in metallurgical chemical, petrochemical, pharmaceutical and textile industries. Therefore, there is a need for a cost effective and efficient means to separate hydrogen from other gases. At present, $\mathrm{H}_{2}$ can be separated/purified using one of three major processes or their combination: (i) pressure swing adsorption (PSA), (ii) fractional/cryogenic distillation, or (iii) membrane separation. While PSA and fractional/cryogenic distillation systems are in commercial operation, 
they are generally not cost effective and especially the fractional/cryogenic distillation is quite energetically demanding for the separation and purification of $\mathrm{H}^{1}$. Concerning low energy consumption, possibility for continuous operation, easy operation and economical construction costs, membrane separation is currently the most promising process for $\mathrm{H}_{2}$ separation/purification [1].

Membranes for gas separation processes require high permeability and selectivity. Moreover, they should have good chemical, thermal and mechanical stability and they should be able to be produced continuously and defect-free. There are several membrane materials for hydrogen separation: metallic (mainly Pd based membranes), polymeric, porous inorganic such as silica, zeolite, oxides (alumina, titania, zirconia), and carbon [2,3]. Palladium-based membranes have high selectivities and permeabilities for hydrogen due to their unique permeation mechanism described by the Sieverts' law [1]. Pure Pd membranes are often damaged by hydrogen embrittlement due to the $\alpha-\beta$ phase transition of palladium hydride which occurs at below the critical temperature $\left(300^{\circ} \mathrm{C}\right)$ and pressure (2 $\mathrm{MPa}$ ) [4,5]; embrittlement can be minimized by alloying palladium with $\mathrm{Ag}, \mathrm{Cu}$ or $\mathrm{Au}$ [6e8]. Another challenge to Pd membranes is that the presence of S- containing compounds such as hydrogen sulphide $\left(\mathrm{H}_{2} \mathrm{~S}\right)$, which poison the membrane [9]. Pd-Au alloys have been found to reduce embrittlement and improve resistance to catalytic poisoning and corrosive degradation by $S$ compounds while giving rise to higher hydrogen permeability than pure Pd $[10,11]$. There is still a lot to improve to resolve the current problems associated with $\mathrm{Pd}$ membranes, such as the low permeation of $\mathrm{H} 2$ at low temperatures and reducing the amount of $\mathrm{Pd}$ used due to its high price. Pacheco Tanaka et al. [12,13], developed a "pore fill" type membrane, where Pd particles are filled in the nano-size pores of a ceramic $(\mathrm{g}-\mathrm{Al} 2 \mathrm{O} 3$ and or $\mathrm{YSZ})$ layer located under the top surface $[12,13]$. This type of membranes use a fraction of Pd that in the conventional film membranes, and are more resistant to embrittlement; $\mathrm{H} 2$ permeation of $8 \times 10^{-8} \mathrm{~mol} \mathrm{~m}^{-2} \mathrm{~s}^{-1} \mathrm{~Pa}^{-1}{ }^{\circ} \mathrm{C}$ and $6 \times 10^{-7}$ mol m${ }^{-2} \mathrm{~s}^{-1} \mathrm{~Pa}^{-1}{ }^{\circ} \mathrm{C}$ at $50^{\circ} \mathrm{C}$ and $100^{\circ} \mathrm{C}$ respectively, were reported.

In the last three decades, gas separation using polymeric membranes has become widely used for a variety of industrial gas separation applications [14]. Among them several mem- branes for hydrogen separation have been studied. In 1979, Monsanto [15] developed the first commercial asymmetric polysulfone hollow fiber membrane and reported a $\mathrm{H}_{2} / \mathrm{N} 2$ selectivity of 39 . Ube Industries in Japan [16] reported a poly- imide membrane with a $\mathrm{H}_{2} / \mathrm{N}_{2}$ selectivity of 35.4 , and Separex [17] studied a membrane of polyimide cellulose acetate and 
reported a selectivity of 33. Robeson [18] concluded that for polymeric membranes there is a tradeoff between selectivity and permeability and the best performing membranes form an "upper bound" in a log-log plot of selectivity versus permeability. In the past years, it is becoming apparent that new permeability data show only modest shifts in the empirical H2/N2 upper bound. Several polymers had become common for hydrogen gas separation membranes, among them are polysulfones (PSF), polycarbonates, cellulose acetate (CA) [19], poly(-phenyllene oxides) (PPO) [20], aramids and polyimides $(\mathrm{PI})$, being the most studied the polyimide Matrimid ${ }^{\circledR}$. Since several industrial processes involve operations at severe temperature and pressure conditions, these are the main drawbacks of polymeric membranes for hydrogen separation compared to inorganic membranes [21].

Silica membranes are one of the candidates for hydrogen separation. They are low cost microporous inorganic membranes with a network of pores of approximately $0.5 \mathrm{~nm}$ of diameter. Silica membranes show low permeation to $\mathrm{H} 2$ and good $\mathrm{H}_{2} / \mathrm{N} 2$ selectivity in dry conditions at 50-600 ${ }^{\circ} \mathrm{C}$; however their stability to water vapor is quite poor, even at room temperature [22-24].

Zeolite membranes are inorganic membranes that have uniform molecular size pores. But the presence of inter- crystal pores with sizes larger than the zeolite pores is the major cause for decline in molecular separation efficiency. Now, research is ongoing to resolve the inter-crystalline diffusion path issue using mixed matrix membranes. Zeolite membranes have shown $\mathrm{H} 2$ permeance ranging from $10^{-7}$ to $<_{10^{-8}} \mathrm{~mol} \mathrm{~m}^{2} \mathrm{~s}^{-1} \mathrm{~Pa}^{-1}$ with a maximum of $\mathrm{H} 2 / \mathrm{N} 2$ selectivity of 4.8 between 35 and $125{ }^{\circ} \mathrm{C}$; to be considered useful for gas separation applications these membranes have to be synthesized without macropore size defects or pinholes [25-27].

Carbon molecular sieve membranes (CMSM) were studied for the separation of hydrogen from gasification gas and purification of methane [28], and recovering of $\mathrm{H}_{2}$ from the waste gas stream [29]. CMSM are inorganic membranes considered as potential candidates for hydrogen separation because of their high mechanical strength and good thermal stability. CMSM are produced by carbonization of a suitable thermo- setting polymeric precursor under an inert atmosphere or vacuum [30e32]. The control over the molecular dimensions of these micropores and the subsequent molecular sieving properties can be tuned by selecting the precursor material and preparation procedure, pre-treatment of the precursor, carbonization temperature history, and post-treatment of the carbonized membranes. The carbonization of polymers in inert or vacuum atmospheres can be separated 
into three processes: (i) annealing at 100-400 ${ }^{\circ} \mathrm{C}$, (ii) intermediate heat- ing at $400 \mathrm{e} 500{ }^{\circ} \mathrm{C}$, and (iii) pyrolysis to form carbon at 500-1000 ${ }^{\circ} \mathrm{C}$ [33]. The pyrolysis process is governed by some parameters such as the heating rate, the final pyrolysis temperature, the thermal soak time, and the pyrolysis atmosphere [34].

Koresh and Soffer [35] prepared membranes carbonizing cellulose hollow fibers. These authors showed the dependence of permeabilities and selectivities on the carbonization temperature and pressure. Hatori [36] reported permeation data of polyimide (Kapton ${ }^{\circledR}$ ) membrane film to $\mathrm{H}_{2}$ and $\mathrm{CO}_{2}$. Their data showed that increasing the carbonization temperature the size of the micropores decreases. CMSM derived from the carbonization of cellulosic films have been shown by Grainger and Hagg to perform better than polymeric membranes for hydrogen/methane separation in terms of the Robeson type plot $[16,18,37]$. Table 1 reviews the permeability to $\mathrm{H}_{2}$ and $\mathrm{H}_{2} / \mathrm{N}_{2}$ permselectivities for carbon molecular sieve membranes.

The carbonization end temperature in the preparation of CMSM is generally chosen to be above the decomposition point of the polymer but below the graphitization temperature $\left(550{ }^{\circ} \mathrm{C}-1000{ }^{\circ} \mathrm{C}\right)$. Koresh and Soffer [38] studied carbonization end temperature in the range of $800^{\circ} \mathrm{C}$ and $950{ }^{\circ} \mathrm{C}$, and found that membranes carbonized at the upper temperature exhibited lower permeabilities but higher permselectivities. Geiszler and Koros [39] studied hollow fiber CMSM derived from 6FDA/BPDAeDAM polyimide precursors and found that increasing the carbonization end temperature from $500{ }^{\circ} \mathrm{C}$ to $800{ }^{\circ} \mathrm{C}$ the permeability decreased but the selectivity increased. Similar trends concerning the permeability and selectivity as a function of carbonization temperature have been obtained for other precursor: Kapton (PMDAeODA pol- yimide) [40], P84 polyimide [41], Matrimid polyimide [42], polypyrrolone [43], BTDAeODA polyimide [44,45], and PFA [46]. Briceño et al. [47] coated $\mathrm{TiO}_{2}$ macroporous tubes in one step with matrimid and pyrolyzed at $550{ }^{\circ} \mathrm{C}-700^{\circ} \mathrm{C}$ under nitrogen. After coating the membrane with a thin film of PDMS to eliminate imperfections and pinholes the authors reported $\mathrm{H}_{2} / \mathrm{N}_{2}$ selectivities of 4.46 and permeance to $\mathrm{H} 2$ of $9.82 \times 10^{-9} \mathrm{~mol} \mathrm{~m}^{-2} \mathrm{~s}^{-1} \mathrm{~Pa}^{-1}$. High pyrolysis temperatures produce increased crystallinity, increased density, and lower average interplanar spacing in CMSM [42,48-51]. In all, for low temperatures, carbon membranes have the potential for a wide variety of applications associated with the separation and purification of hydrogen gas.

Campo et al. [52] prepared CMSM from cellophane paper using a single pyrolysis step and found that the permeability reached a maximum at $550{ }^{\circ} \mathrm{C}$, 
without compromising the selectivity. The Robeson upper bound was overtaken regarding $\mathrm{H}_{2} / \mathrm{N}_{2}$ separation with a permselectivity of 390. Our group [53] had prepared supported composite-CMSMs (c- CMSMs) derived from resolphenolic resin loaded with boehmite nanoparticles in a single dippingdrying- carbonization step of a tubular a-alumina membrane sup- port. After carbonization at $550^{\circ} \mathrm{C}$ a selectivity of 14 for the separation of $\mathrm{C} 3 \mathrm{H} 6 / \mathrm{C} 3 \mathrm{H} 8$ was reported; the addition of silver enhanced the selectivity to 38 [54]. CMSM were also prepared varying the composition of resol and boehmite leading to the formation of c-CMSM with different carbon/A12O3; it was found that membranes with higher carbon/A12O3 ratio showed higher permeabilities and lower selectivities; for $\mathrm{H} 2$ a permeability of 2047 barrer and a selectivity for $\mathrm{H}_{2} / \mathrm{N}_{2}$ of 65.6 was reported [55]. CMSM prepared from resorcinolformaldehyde resin loaded with boehmite nanoparticles and carbonized at 550 ${ }^{\circ} \mathrm{C}$ presented micropores with narrower pore-size distribution and higher selectivities than those carbonized at $500{ }^{\circ} \mathrm{C}$; a H2 permeability of 301 barrer and selectivity of $\mathrm{H} 2 / \mathrm{N} 2>586$ was reported [56] surpassing the Robeson upper bound for polymeric membranes. c-CMSMs were also prepared using novolac phenolic resin and boehmite nanoparticles in a single dipping-dryingcarbonization step on top of a a- $\mathrm{Al} 2 \mathrm{O} 3$ tubular membrane support; the decrease in performance of the Al-CMSM due to air exposure (aging by adsorption of water), and the changes in the transport properties of the membranes with different activation temperatures for removing water present in the pores were studied using pure gas permeation [57].

This paper studies the effect of the carbonization end temperature in the preparation of c-CMSM using novolac resin and boehmite coated on a- $\mathrm{Al}_{2} \mathrm{O}_{3}$ tubular membrane support, and their effect in the permeation properties for hydrogen separation at low temperatures.

These carbon membranes can be used for hydrogen separation from reforming gas, after water gas shift to produce power generation and/or chemical grade hydrogen, at temperatures above $250{ }^{\circ} \mathrm{C}$ and pressures above 13 bar and in the presence of impurities such as $\mathrm{H} 2 \mathrm{~S}$ and NH3 [58]. These membranes can also be used to produce oxygen-enriched streams from air, concentrate methane from biogas and xenon from xenon containing streams. 


\section{Experimental}

\section{Materials}

The novolac resin (phenol formaldehyde resin) used as polymeric precursor was synthesized by the acid-catalyzed phenol-formaldehyde condensation [62] as described elsewhere [57]. Briefly, phenol and oxalic acid were placed in a flask fitted with stirrer and a reflux condenser, when the solution reached $80^{\circ} \mathrm{C}$ formaldehyde was added drop-wise, the resin was washed with hot water and further dried. N-methyl- 2-pyrrolydone. (NMP), 99.8\% purity was supplied by Sigma-Aldrich. Boehmite (10 wt\%) particle size $8 \mathrm{e} 20 \mathrm{~nm}$, was provided by Kawaken Fine Chemicals Co. Ltd. The a-alumina tubular supports were supplied by Inopor. Non-porous alumina tubes were purchased from Omega Engineering. The gases were supplied by Air Liquid (99.999\% pure). Other chemicals were of reagent grade.

\section{Preparation of tubular ceramic supports}

The ends of porous a- $\mathrm{Al} 2 \mathrm{O} 3$ supports (length $70 \mathrm{~mm}$, and external diameter of $10 \mathrm{~mm}$ ) were attached to non-porous $\mathrm{Al}_{2} \mathrm{O} 3$ tubes and sealed with a glass sealant at $1150{ }^{\circ} \mathrm{C}$. The supports have $200 \mathrm{~nm}$ mean pore size, located in the outer part of the tube, an effective length of $50 \mathrm{~mm}$ was left in the middle.

\section{Preparation of the carbon molecular sieve membranes}

Novolac polymer precursor was dissolved in NMP to prepare a $36 \mathrm{wt} \%$ resin solution and stirred thoroughly for $24 \mathrm{~h}$ to form a homogenous solution. A coating solution containing $13 \mathrm{wt} \%$ of novolac resin, $2.4 \mathrm{wt} \%$ of formaldehyde, a $0.6 \mathrm{wt} \%$ of ethylenediamine and a $83.2 \mathrm{wt} \%$ of NMP was prepared, and heated at $100{ }^{\circ} \mathrm{C}$ for $2 \mathrm{~h}$ for polymerization; then, a $0.8 \mathrm{wt} \%$ dispersion of boehmite nanoparticles was added. The a-alumina tube was coated with this solution by dip-coating using a vacuum pump. The remaining precursor solution was placed in a Teflon dish to make unsupported composite films used for morphological and pore size distribution characterization. Both supported and unsupported membranes were dried in an oven at $100{ }^{\circ} \mathrm{C}$ overnight. The tubular supported membranes were dried under continuous rotation inside an oven to guaranty thickness uniformity.

The membranes were carbonized in a Termolab tubular oven inside a quartz tube (80 $\mathrm{mm}$ diameter and $1.5 \mathrm{~m}$ in length), using N2 at flowing 
rate of approximately $150 \mathrm{ml} \mathrm{min}^{-1}-200 \mathrm{ml} \mathrm{min}^{-1}$. First, the temperature was raised from ambient to $100{ }^{\circ} \mathrm{C}$ at a rate of $1^{\circ} \mathrm{C} \mathrm{min}^{-1}$ and held at this temperature for $30 \mathrm{~min}$. Then, the temperature was increased from $100^{\circ} \mathrm{C}$ to the desired end temperature with a heating rate of $1^{\circ} \mathrm{C} \mathrm{min}^{-1}$ and a soaking time of $2 \mathrm{~h}$. Finally, the oven was allowed to gradually cool to room temperature prior to the removal of the samples. For "fresh membranes", the permeation was determined as soon as the carbon membranes were taken from the oven. The unsupported films were either crushed into small flakes or milled before morphological characterization. c-CMSM were prepared by carbonization at 450, 500, 550, 600, 650, 700, 750, 800, 850 and 1000 ${ }^{\circ} \mathrm{C}$ e named CMSMT, where $T$ is the carbonization end temperature (i.e. CMSM500 for a carbonization end temperature of $\left.500{ }^{\circ} \mathrm{C}\right)$. At least three membranes for each temperature were prepared. Immediately after carbonization (exposure to air less than $20 \mathrm{~s}$ ) permeation experiments were performed; these are named "fresh membranes" e letter $F$ added to the membrane name (i.e. CMSM500-F). After 1 day of exposure to air at room temperature, more gas permeation tests were carried out e named CMSMT-1d (i.e. CMSM500-1d indicates a carbon membrane carbonized at $500{ }^{\circ} \mathrm{C}$ and doing the permeation test after 1 day).

After approximately 5 months in the air, membrane CMSM500 (named CMSM500-5m) was heat treated (activated) at various temperatures $\left(100{ }^{\circ} \mathrm{C}, 120\right.$ ${ }^{\circ} \mathrm{C}, 140^{\circ} \mathrm{C}, 160{ }^{\circ} \mathrm{C}, 180^{\circ} \mathrm{C}$ and $200{ }^{\circ} \mathrm{C}$ ) under $\mathrm{N} 2$ (heating rate $0.7^{\circ} \mathrm{C}$ min ${ }^{-1}$, soaking time of $120 \mathrm{~min}$ ) in order to remove water from the pores. After activation, the membrane was left in the oven to cool under N2 atmosphere and then permeation experiments $\left(\mathrm{N}_{2}, \mathrm{O}_{2}, \mathrm{He}, \mathrm{H} 2, \mathrm{CO} 2\right)$ were carried at various feed pressures $(100 \mathrm{kPa}-500 \mathrm{kPa})$ and temperatures $\left(20^{\circ} \mathrm{C}-100{ }^{\circ} \mathrm{C}\right)$; the permeation tests were carried for each activation temperature.

Carbon membranes carbonized at 4 different temperatures after approximately 5 months of aging in air (CMSM500-5m, CMSM550-5m, CMSM600-5m and CMSM650-5m) were activated at $200{ }^{\circ} \mathrm{C}$ under $\mathrm{N} 2$ at a heating rate of $0.7{ }^{\circ} \mathrm{C}$ $\min ^{-1}$ and soaking time of $120 \mathrm{~min}$. Then, as mentioned before, permeation tests were carried at different pressures and temperatures and for different gases. 
Scanning electron microscopy analysis (SEM)

SEM images of the c-CMSMs were taken using a FEI Quanta 400 FEG/EDAX Genesis X4M microscope with $1.2 \mathrm{~nm}$ resolution. The tubular supported c-CMSM were fractured and sputtered with platinum to allow better conductivity for SEM.

\section{Raman analysis}

Raman analysis were performed on crushed composite-CMSM films using a Renishaw HP IR 785 spectrometer using a $514 \mathrm{~nm}$ green laser (Laser physics 25S-514). The spectra were recorded in the range of $500-2000 \mathrm{~cm}^{-1}$, at beam power between 25 and 100 $\mathrm{mW}$ Helium-Neon laser with the laser beam focused to a spot size of the order of $2 \mathrm{~mm}$.

\section{Pore size characterization}

The microporosity of the composite-CMSM was assessed from the CO2 adsorption isotherm at $0{ }^{\circ} \mathrm{C}$. The equilibrium values were obtained using a gravimetric method set up in a Rubotherm ${ }^{\circledR}$ magnetic suspension balance $\left( \pm 10^{-5} \mathrm{mg}\right.$ precision) as described elsewhere [63]. The samples were regenerated with helium at $70^{\circ} \mathrm{C}$ before the measurement.

\section{Gas permeation measurements}

For the permeation tests, a shell-and-tube test bench was used, as described elsewhere [53]. Briefly, the test bench uses a pressure controller (Horiba Stec, model UR-7340) for the feed stream and a soap-bubble-film flow meter (STEC SF-2 and STEC SF-3) to measure the permeate flow rate; the temperature was controlled by placing the system into a splitting oven which has three independent heating zones. The selected gas $\left(\mathrm{N}_{2}, \mathrm{O} 2, \mathrm{He}, \mathrm{H} 2\right.$ or $\left.\mathrm{CO} 2\right)$ was introduced into the membrane tube from outer shell and the gas permeated was led to the flow meter; flows at various feed pressure differences (100e500 $\mathrm{kPa}$ ) and at a given temperature were carried and used to calculate the permeance; the average of the permeance are reported.

\section{Results and discussion}

Scanning electron microscopy analysis (SEM)

Fig. 1 shows the microphotograph of the cross-sectional view of a CMSM carbonized at $550{ }^{\circ} \mathrm{C}$. It can be observed a distinct thin layer of the carbon 
membrane that was uniformly coated on top of the $\alpha-\mathrm{Al}_{2} \mathrm{O} 3$ support with about $4 \mu \mathrm{m}$ thickness.

\section{Raman analysis}

Raman spectroscopy has been frequently used for characterizing crystalline, nanocrystalline and amorphous carbons. Raman spectra of graphitic carbons consists of two bands, the $G$ (graphitic) band at $1575 \mathrm{~cm}^{-1}$ and the $D$ (disordered graphitic) band at $1355 \mathrm{~cm}^{-1}$ [64]. c-CMSM samples carbonized from 500 to $700^{\circ} \mathrm{C}$ were characterized using Raman spectroscopy e Fig. 2; the spectra were recorded in the range of 500-2000 $\mathrm{cm}^{-1}$. It can be seen the presence of two major characteristic bands. First, the graphite band (G-band), generally located at $1575 \mathrm{~cm}^{-1}$ corresponding to the $\mathrm{sp}^{2}$ binding structures caused by the stretching vibrations of the C-C bonds, are shifted towards 1580-1596 $\mathrm{cm}^{-1}$, which is characteristics of the carbon materials with disorderedcarbon [65]. Second, the disordered band (D-band), located between 1300 and $1400 \mathrm{~cm}^{-1}$, which is usually found in amorphous carbon. ID (intensity of the disordered band) and IG (intensity of the graphite band) ratios were used to deter- mine the ratio between disordered and organized phases of carbon in the CMSM samples [65]. As shown in Table 2, the intensity of the D-band increases with the temperature, increasing the disorder, corresponding to an increase in amorphous carbon. The same trend was observed by Evelyn et al.[66] using Raman spectroscopy. The fractional value for the amount of disordered carbon, $f$, which is related to the intensity of bands $D$ and $G$ according with eq. (1) also evidences the increasing amount of disordered carbon [67] - Table 2.

$$
f=\frac{I_{D}}{I_{D+I_{G}}}
$$

\section{Pore size characterization}

The adsorption equilibrium isotherms of $\mathrm{CO} 2$ at $0{ }^{\circ} \mathrm{C}$ exhibit type I behavior for the c-CMSM samples carbonized at four different temperatures. The adsorption equilibrium values were obtained using a Rubotherm ${ }^{\circledR}$ suspension magnetic balance [63]. Fig. 3 plots the adsorption equilibrium isotherms of $\mathrm{CO} 2$ at $0^{\circ} \mathrm{C}$ on c-CMSM crashed flakes, treated at different temperatures $\left(450^{\circ} \mathrm{C}, 550\right.$ ${ }^{\circ} \mathrm{C}, 650^{\circ} \mathrm{C}$ and $\left.750{ }^{\circ} \mathrm{C}\right)$. 
The adsorption mechanism in micropores is known as micropore filling and has been well described by Dubinin and co-workers [68,69]. DubininRadushkevisch (DR) equation was used to fit the experimental results:

$$
\frac{\mathrm{W}}{\mathrm{W}_{0}}=\exp \left[-\left(\frac{\mathrm{RT} \ln \left(\mathrm{P}_{0} / \mathrm{P}\right)}{\mathrm{E}_{0}}\right)^{2}\right]
$$

where $W$ refers to the micropore volume filled at pressure $P, W 0$ is the total micropore volume, $E 0$ the characteristic energy, $P 0$ the vapor pressure of the free liquid, $R$ is the gas constant and $T$ is the absolute temperature. DR equation gives a reasonable description of adsorption in micropores when the relation obtained for $\mathrm{CO} 2$ is linear. Another equation was proposed, the Dubinin-Astakhov (DA) [70] equation:

$$
\frac{\mathrm{W}}{\mathrm{W}_{0}}=\exp \left[-\left(\frac{\mathrm{RT} \ln \left(\mathrm{P}_{0} / \mathrm{P}\right)}{\mathrm{E}_{0}}\right)^{n}\right]
$$

where $n$ is a fitting parameter. The adsorption isotherms of CO2 on c-CMSM are not linear and, therefore, the micropore volume and the characteristic energy were determined fitting the Dubinin-Astakhov equation to the experimental data. Fig. 4 presents the curve for c-CMSM.

The suitability and the applicability of the DA equation were assessed from Fig. 5; since straight fitting line were obtained the DA equation is suitable for these samples. The slope of the plot is related to the characteristic energy of the micropore and the intercept is related to the micropore volume. Table 3 lists the structural parameters obtained for the studied samples.

To obtain a more detailed knowledge of the porous structure of the c-CMSM, their pore size distribution (PSD) was determined using the structure-based method developed by Nguyen et al. [71,72]. Briefly, the method uses the Langmuir isotherm for all pores of size $r$, while the heterogeneity of the system is described by the distribution of micropores with different size, given by $f(r)$. This method takes into account the potential energy $(E)$ when a molecule is adsorbed on a flat surface, ES, and the potential energy when a molecule is adsorbed inside a pore, Epore. A slit like pore configuration is assumed here considering the interaction potential energy between graphite type walls and the probe gas molecule. Additionally this model distinguishes between the gas confined in the pore and the adsorbed state and considers the overall contribution of every pore. Further details about this method can be found elsewhere [71,73]. The pore size distribution for c-CMSM carbonized at 450, 550, 650 and $750^{\circ} \mathrm{C}$ were obtained and are presented in Figs. 5 and 6. 
It can be seen from Figs. 5 and 6 that the c-CMSM samples show both the presence of small micropores ( $0.3 \mathrm{~nm}-0.7 \mathrm{~nm}$ range) and larger micropores (0.7 $\mathrm{nm}-1 \mathrm{~nm}$ ). Sample CMSM- 450 has a small volume of pores with pores ranging from $0.4 \mathrm{~nm}$ to $0.9 \mathrm{~nm}$ and sample CMSM-550 has a significant higher pore volume and pores ranging from $0.45 \mathrm{~nm}$ to $0.8 \mathrm{~nm}$; sample CMSM-650 shows a higher pore volume and a bidisperse pore size distribution with a significantly larger volume of small micropores (0.35 nm- $0.45 \mathrm{~nm}$ ); finally sample CMSM- 750 exhibits a smaller volume of small micropores (0.35 nm-0.45 nm) and a larger volume of intermediate size micropores $(0.5-0.8 \mathrm{~nm})$ with a very defined pore size distribution of pores ranging between $0.35 \mathrm{~nm}$ and $0.45 \mathrm{~nm}$ normally assigned to the permselectivity behavior of the membrane. These results show that as the carbonization temperature increases the volume and the number of smaller micropores increases up to $650{ }^{\circ} \mathrm{C}$. This will influence the permeability and permselectivity performance of the carbon membranes, as it will be shown below. The results are consistent with the PSD found for c-CMSM derived from the resol resin [53] showing both small and larger micropores (0.35$0.45 \mathrm{~nm}$ and $0.5-0.8 \mathrm{~nm}$ ). The pore size distribution determined is also consistent with the permeation results shown in Table 4 where the permeability increases from CMSM-450 to CMSM-650 correlating well with the increase of the pore volume and the selectivity increases for sample CMSM-750 where pore constrictions volume pores ranging between $0.35 \mathrm{~nm}$ and $0.45 \mathrm{~nm}$ is well defined.

\section{Permeation experiments}

Effect of carbonization end temperature on the permeation of "fresh membranes" The permeance of the supported carbon membranes obtained from $450{ }^{\circ} \mathrm{C}$ to $1000^{\circ} \mathrm{C}$ was evaluated for N2 (0.364 nm [74]), and $\mathrm{O} 2$ (0.346 nm [74]) e the values in brackets correspond to the kinetic diameter of the gases. Permeation experiments were carried at room temperature just after the membrane carbonization (fresh membranes) to prevent the adsorption of water; the exposure to air was less than $20 \mathrm{~s}$. The duration of each permeation test was ca. $2 \mathrm{~h}$, the gas permeation measurements were made until readings stabilize. Throughout the various test phases, membrane performance was periodically evaluated using pure gas permeation tests (with He or N2). The permeances and ideal permselectivities for the fresh carbon membranes are summarized in Table 4 and the effect of carbonization end temperature on the permeances to N2 and $\mathrm{O} 2$ are shown in Fig. 7. For both gases all membranes showed high permeances, though small selectivities; from $450{ }^{\circ} \mathrm{C}$, the permeation increases as the 
carbonization end temperature increases peaking between $500{ }^{\circ} \mathrm{C}$ and $700{ }^{\circ} \mathrm{C}$. These results show that the permeation depends on the carbonization end temperature; at $450^{\circ} \mathrm{C}$ few pores are formed and as the temperature increases more functional groups are removed producing more pores; from $650{ }^{\circ} \mathrm{C}$ condensation reactions are predominant therefore smaller pores are formed decreasing the gas permeation. These results are consistent with the pore size distribution shown in Figs. 5 and 6 where it was seen that as the carbonization temperature increases the volume and the number of smaller micropores up to $650{ }^{\circ} \mathrm{C}$, and for the sample carbonized at $750{ }^{\circ} \mathrm{C}$ the selectivity increases.

Effect of carbonization end temperature on the permeation of "aged membranes" (1 day).

The fresh membranes were left in the laboratory bench at room temperature for 1 day. Then the permeance and selectivities of the c-CMSM samples to O2, N2, He and $\mathrm{H} 2$ were obtained (Table 5). Compared with fresh membranes (Table 4), the permeances decreased more markedly for N2 (700 times for N2 and 66 times for O2); samples carbonized at temperatures above $600{ }^{\circ} \mathrm{C}$ showed permeance out of the range of the flow-meter used. The decrease of permeation after 1 day should be related to the reaction of reactive groups presented in the fresh membrane with water producing functional groups containing oxygen (chemisorption), making the pores smaller and hydrophilic, able to adsorb water ([75e78] physisorption). O2/N2 permselectivity increases with the temperature; for the membrane calcinated at $550{ }^{\circ} \mathrm{C}$ this value was 15 . Permselectivities for higher carbonization end temperatures were not possible to measure.

Since $\mathrm{H}_{2}$ and $\mathrm{He}$ are smaller, permeance studies for these two gases were carried out and their relation with the temperature of carbonization is shown in Fig. 8 and Table 5; highest permeance are observed for samples carbonized at 500 and $550{ }^{\circ} \mathrm{C}$. These carbon membranes show higher permeance for $\mathrm{H} 2$ than for He despite of $\mathrm{H}_{2}$ being larger than helium $(0.29$ and $0.26 \mathrm{~nm}$ for $\mathrm{H} 2$ and $\mathrm{He}$, respectively) [74]; this was attributed to the larger adsorption affinity of $\mathrm{H} 2$ [40] and to the cross-section diameter of $\mathrm{H} 2$, which is smaller. In Fig 9 the revised Robeson upper bound line for $\mathrm{H} 2 / \mathrm{N} 2$ separation, including some representative state of the art membrane values [77], and the experimental values obtained in the pre- sent work, are presented. Sample CMSM550-1d (C1) is located above the upper bound line and is located between the performances of $\mathrm{Pd}$ pore filled membranes at $100{ }^{\circ} \mathrm{C}(\mathrm{Pd} 1)$ and at $50{ }^{\circ} \mathrm{C}(\mathrm{Pd} 2)$ [12]. The $\mathrm{Pd}$ membrane 
permeation to hydrogen decreases with the temperature; below $100{ }^{\circ} \mathrm{C}$ it is low and membranes are sensitive to embrittlement. Pore filled type membranes, however, are more resistant towards embrittlement and therefore these values were used as comparison.

Since CMSM are: a) cheaper, b) embrittlement free, and c) resistant to sulfur or carbon monoxide poisoning, they are more suitable for hydrogen separation at low temperatures.

Permeation studies of membrane carbonized at $500^{\circ} \mathrm{C}$ after 5 months of aging.

Since the aged membranes have low gas permeation due to the water presence in the pores, the effect of removing that water by heating (activation) was studied. The c-CMSM sample carbonized at $500^{\circ} \mathrm{C}$ and aged for approximately 5 months (c-CMSM500-5m) was activated under $\mathrm{N}_{2}$ flow at $200^{\circ} \mathrm{C}$, with a heating rate of $0.7^{\circ} \mathrm{C} / \mathrm{min}$ and soaking time of $120 \mathrm{~min}$. Permeation tests were performed with $\mathrm{N}_{2}, \mathrm{O}_{2}, \mathrm{He}, \mathrm{H}_{2}$ and $\mathrm{CO}_{2}$ and at different permeation temperatures (from $40{ }^{\circ} \mathrm{C}$ to $120^{\circ} \mathrm{C}$ ) and at different feed pressure (from $100 \mathrm{kPa}$ to $500 \mathrm{kPa}$ ). The permeance values obtained are given in Fig. 10. Similar permeation tests were carried for c-CMSM500-5m sample activated at $100{ }^{\circ} \mathrm{C}, 120{ }^{\circ} \mathrm{C}, 140{ }^{\circ} \mathrm{C}, 160{ }^{\circ} \mathrm{C}$, $180{ }^{\circ} \mathrm{C}$, and $200^{\circ} \mathrm{C}$; the permeance values for each pressure were calculated and the average of these values are listed in Supplementary information S1.

Fig. 11 shows the Arrhenius plot for the membrane activated at $120{ }^{\circ} \mathrm{C}$. From the data of permeance at different temperatures of the activated c-CMSM-500$5 \mathrm{~m}(\mathrm{~S} 1)$, the activation energy $(E a)$ was calculated.

$$
\operatorname{Ln} J=\frac{E_{a}}{R}\left(\frac{1}{T}\right)+c
$$

The values of $E_{a}$ of c-CMSM-500-5m for $\mathrm{N}_{2}, \mathrm{O}_{2}, \mathrm{He}, \mathrm{H}_{2}$ and $\mathrm{CO}_{2}$ are listed in Table 6 and illustrated in Fig. 12.

Fig. 12, shows that a) for all gases $E a$ increases with the permeant size; for bulkier molecules the energy needed to pass through the pores is higher; b) Ea decreases as the temperature of carbonization of the membrane increases; c) for $\mathrm{CO} 2$, at temperatures lower than $200{ }^{\circ} \mathrm{C}, E a$ values are higher than bulkier species $\mathrm{N}_{2}$ and $\mathrm{O} 2$. The permeation behavior of $\mathrm{CO}_{2}$ should be related to the fact of $\mathrm{CO} 2$ presenting a high adsorption affinity towards CMSMs. Assuming sorption- diffusion transport mechanism, since $\mathrm{CO} 2$ adsorption is lower at higher temperatures makes the $\mathrm{CO} 2$ transport in these conditions less favorable 
(Fig 12).

Permeation studies of the membranes carbonized at various temperatures and heated at $200^{\circ} \mathrm{C}$

Carbon membranes c-CMSM500-5m, c-CMSM550-5m, c- CMSM600-5m and cCMSM650-5m were activated under $\mathrm{N} 2$ at $200{ }^{\circ} \mathrm{C}$, with a heating rate of $0.7^{\circ} \mathrm{C}$ $\min ^{-1}$, for $120 \mathrm{~min}$. The permeation to $\mathrm{N} 2, \mathrm{O} 2, \mathrm{CO} 2, \mathrm{H} 2$ and He were obtained and results are listed in the Supplementary information S2. From these values, $E a$ were calculated using eq. (4) and the results are listed in Table 7 and illustrated in Fig 13.

$E a$ increases with the kinetic diameter of the gases for c- CMSM carbonized at more than $600{ }^{\circ} \mathrm{C}$. It is more difficult for N2 to permeate because pores became smaller. Membranes carbonized at more than $650^{\circ} \mathrm{C}$ show too small permeances to $\mathrm{N}_{2}, \mathrm{O}_{2}$, and $\mathrm{CO}_{2}$ to be detected and only the permeance to fast species $\mathrm{H}_{2}$ and $\mathrm{He}$ were measured. $\mathrm{H} 2$ has higher $\mathrm{Ea}_{a}$ than $\mathrm{H}_{2}$ which increases as the carbonization temperature increases; another indication that the pore size decreases with the temperature. $E a$ for $\mathrm{CO} 2$ in membranes activated at $200{ }^{\circ} \mathrm{C}$ are in line with its size (see Fig. 13).

Fig. 14 presents the revised Robeson upper bound line [77] for $\mathrm{H} 2 / \mathrm{CO} 2$ including values from the literature and from this work. It can be seen that CMSM600 membrane activated at $200{ }^{\circ} \mathrm{C}$ and characterized at $30^{\circ} \mathrm{C}$ (CMSM60030) exceeds the upper bound.

\section{Conclusions}

Thin composite alumina CMS membranes were successfully fabricated by carbonizing novolac phenolic resin coated on $\alpha$-alumina tubular membranes using a single dip step. It was concluded that the carbonization end temperature was important for the permeation characteristics of the membranes; the pore size decreases with the carbonization temperature within $450{ }^{\circ} \mathrm{C}-1000^{\circ} \mathrm{C}$ temperature range.

Membrane samples just after carbonization show high gas permeation that decreases quickly upon contacting with room atmosphere; this behavior was assigned to the water physical and chemical adsorption on the pore network. After 1 day contacting with the atmospheric air, the membrane carbonized at 550 ${ }^{\circ} \mathrm{C}$ showed an $\mathrm{O} 2 / \mathrm{N} 2$ selectivity of 15 at room temperature and performs above 
the Robeson upper bound; the $\mathrm{H}_{2} / \mathrm{N} 2$ selectivity was 725 and the permeance to H2 was $145 \times 10^{-9} \mathrm{~mol} \mathrm{~m}^{-2} \mathrm{~s}^{-1} \mathrm{~Pa}^{-1}$ at room temperature, values comparable with the best performing to Pd membranes. This CMS membrane can therefore be used instead of $\mathrm{Pd}$ for $\mathrm{H} 2$ separation processes involving hydrogen membranes at low temperature. The gas permeation of aged membranes can be increased heating them from $100{ }^{\circ} \mathrm{C}$ to $200{ }^{\circ} \mathrm{C}$; this enhancement was assigned to the removal of physically adsorbed water. From the gas permeation at different feed pressures and temperatures, it was possible to calculate the permeation activation energy, $E_{a}$ for $\mathrm{N}_{2}, \mathrm{O} 2, \mathrm{CO} 2, \mathrm{He}$ and $\mathrm{H} 2$; the permeation increases as the water is removed and the $E a$ increases with the size of the permeant species; below $200{ }^{\circ} \mathrm{C}, \mathrm{CO} 2$ has a higher activation energy than expected according to its size, this due to the permeation mechanism of molecular sieving and adsorption

\section{Acknowledgments}

Margot Llosa Tanco is grateful to the Portuguese Foundation for Science and Technology (FCT) for her doctoral grant (reference SFRH/BD/61898/2009). The authors would like to acknowledge to Sandra C. Rodrigues (doctoral grant reference SFRH/BD/90208/2012) for performing the CO2 adsorption measurements at LEPABE and FCT research project PTDC/ EQU-EQU/114944/2009. The authors are also thankful to CEMUP for the SEM analysis (REEQ/1062/CTM/2005 and REDE/ 1512/RME/2005 funding provided by FCT).

\section{Appendix A. Supplementary data}

Supplementary data related to this article can be found at http://dx.doi.org/10.1016/j.ijhydene.2014.11.025.

\section{References}

1. Ockwig NW, Nenoff TM. Membranes for hydrogen separation. Chem Rev Oct. 2007;107(10):4078-110.

2. Basile Angelo, Gallucci Fausto. Membranes for membrane Reactors: preparation, optimization and selection. John Wiley Sons, Ltd. Publ; 2011.

3. Lin YS. Microporous and dense inorganic membranes: current status and prospective. Sep Purif Technol Oct. 2001;25(1e3):39-55. 
4. Paglieri SN, Way JD. "Innovations in palladium membrane research. Sep Purif Rev Jul. 2002;31(1):1-169.

5. Roa F, Block MJ, Way JD. The influence of alloy composition on the H2 flux of composite Pd Cu membranes. Desalination Sep. 2002;147(1-3):411-6.

6. Pacheco Tanaka DA, Llosa Tanco MA, Niwa S, Wakui Y, Mizukami F, Namba T, et al. Preparation of palladium and silver alloy membrane on a porous a-alumina tube via simultaneous electroless plating. J Memb Sci Feb. 2005;247(1e2):21-7.

7. Okazaki J, Pacheco Tanaka DA, Llosa Tanco MA, Wakui Y, Mizukami F, Suzuki TM. Hydrogen permeability study of the thin Pd-Ag alloy membranes in the temperature range across the $\alpha-\beta$ phase transition. J Memb Sci Oct. 2006;282(1-2):370-4.

8. Okazaki J, Ikeda T, Pacheco Tanaka DA, Sato K, Suzuki TM, Mizukami F. An investigation of thermal stability of thin palladium-silver alloy membranes for high temperature hydrogen separation. J Memb Sci Jan. 2011;366(1-2):212-9. 9. C, T, F J, Gabitto. Sulfur poisoning of metal membranes for $\mathrm{H} 2$ separation. 2009.

10. Ma YH, Mardilovich IP, Engwall EE. Thin composite palladium and palladium/alloy membranes for hydrogen separation. Ann N Y Acad Sci Mar. 2003;984(1):346-60.

11. Yun S, Ted Oyama S. Correlations in palladium membranes for hydrogen separation: a review. J Memb Sci Jun. 2011;375(1-2):28-45.

12. Pacheco Tanaka DA, Llosa Tanco MA, Nagase T, Okazaki J, Wakui Y, Mizukami F, et al. Fabrication of hydrogen- permeable composite membranes packed with palladium nanoparticles. Adv Mater Mar. 2006;18(5):630-2.

13. Pacheco Tanaka DA, Llosa Tanco MA, Okazaki J, Wakui Y, Mizukami F, Suzuki TM. Preparation of 'pore-fill' type PdeYSZeg-Al2O3 composite membrane supported on $\alpha-\mathrm{Al} 2 \mathrm{O} 3$ tube for hydrogen separation. J Memb Sci Jul. 2008;320(1-2):436-41.

14. Sanders DF, Smith ZP, Guo R, Robeson LM, McGrath JE, Paul DR, et al. Energy-efficient polymeric gas separation membranes for a sustainable future: a review. Polym Guildf Aug. 2013;54(18):4729-61.

15. Henis, Tripodi. Multicomponent membranes for gas separations. 4230463. 1980.

16. Grainger D, Hagg $M$. The recovery by carbon molecular sieve membranes of hydrogen transmitted in natural gas networks. Int J Hydrogen Energy May 2008;33(9):2379-88.

17. Schell W, Houston C. Spiral-wound permeators for purification and recovery. Chem Eng Prog 1982;78(10):33-7. 
18. Robeson LM. Correlation of separation factor versus permeability for polymeric membranes. J Memb Sci Oct. 1991;62(2):165-85.

19. Puleo AC, Paul DR, Kelley SS. The effect of degree of acetylation on gas sorption and transport behavior in cellulose acetate. J Memb Sci Dec. 1989;47(3):301-32.

20. Koros WJ, Fleming GK, Jordan SM, Kim TH, Hoehn HH. Polymeric membrane materials for solution-diffusion based permeation separations. Prog Polym Sci Jan. 1988;13(4):339-401.

21. Hosseini SS, Teoh MM, Chung TS. Hydrogen separation and purification in membranes of miscible polymer blends with interpenetration networks. Polym Guildf Mar. 2008;49(6):1594-603.

22. Morooka S, Kusakabe K. Microporous inorganic membranes for gas separation. MRS Bull Mar. 1999;24(03):25-9.

23. Prabhu AK, Oyama ST. Highly hydrogen selective ceramic membranes: application to the transformation of greenhouse gases. J Memb Sci Aug. 2000;176(2):233-48.

24. Verweij H. Ceramic membranes: morphology and transport. J Mater Sci Dec. 2003;38(23):4677-95.

25. Nomura M, Yamaguchi T, Nakao S. Silicalite membranes modified by counter diffusion CVD technique. Ind Eng Chem Res Oct. 1997;36(10):4217-23.

26. Pechar T, Kim S, Vaughan B, Marand E, Tsapatsis M, Jeong H, et al. Fabrication and characterization of polyimideezeolite $\mathrm{L}$ mixed matrix membranes for gas separations. J Memb Sci Jun. 2006;277(1-2):195-202.

27. Husain S, Koros WJ. Mixed matrix hollow fiber membranes made with modified HSSZ-13 zeolite in polyetherimide polymer matrix for gas separation. J Memb Sci Feb. 2007;288(1-2):195-207.

28. Fuertes A, Centeno T. Preparation of supported carbon molecular sieve membranes. Carbon N Y Mar. 1999;37(4):679-84.

29. Rao MB, Sircar S. Nanoporous carbon membranes for separation of gas mixtures by selective surface flow. J Memb Sci Dec. 1993;85(3):253-64.

30. Saufi S. Fabrication of carbon membranes for gas separationeea review. Carbon N. Y 2004;42(2):241-59.

31. Salleh WNW, Ismail AF. Effects of carbonization heating rate on $\mathrm{CO}_{2}$ separation of derived carbon membranes. Sep Purif Technol Mar. 2012;88:17483.

32. Ismail A, David L. A review on the latest development of carbon membranes for gas separation. J Memb Sci Oct. 2001;193(1):1-18.

33. Barsema J, Klijnstra S, Balster J, Vandervegt N, Koops G, Wessling M. Intermediate polymer to carbon gas separation membranes based on matrimid 
PI. J Memb Sci Jul. 2004;238(1-2):93-102.

34. F HC, Ismail AF, Rana D, Matsuura T. Carbon-based membranes for separation processes. Springer; 2011.

35. Koresh JE, Soffer A. The carbon molecular sieve membranes. General properties and the permeability of $\mathrm{CH} 4 / \mathrm{H} 2$ mixture. Sep Sci Technol Feb. 1987;22(2-3):973-82.

36. Hatori H, Takagi H, Yamada Y. Gas separation properties of molecular sieving carbon membranes with nanopore channels. Carbon N. Y Jan. 2004;42(56):1169-73.

37. Grainger D, H£gg M-B. Evaluation of cellulose-derived carbon molecular sieve membranes for hydrogen separation from light hydrocarbons. J Memb Sci Dec. 2007;306(1-2):307-17.

38. Koresh J, Soffer A. 185. A molecular sieve carbon membrane for continuous process gas separation. Carbon N. Y Jan. 1984;22(2):225.

39. Geiszler VC, Koros WJ. Effects of polyimide pyrolysis conditions on carbon molecular sieve membrane properties. Ind Eng Chem Res 1996;35(9):2999-3003. 40. Suda H, Haraya K. Gas permeation through micropores of carbon molecular sieve membranes derived from kapton polyimide. J Phys Chem B 1997;101(96):3988-94.

41. Tin PS, Chung T-S, Liu Y, Wang R. Separation of CO2/CH4 through carbon molecular sieve membranes derived from P84 polyimide. Carbon N Y Jan. 2004;42(15):3123-31.

42. Xiao Y, Dai Y, Chung T-S, Guiver MD. Effects of brominating matrimid polyimide on the physical and gas transport properties of derived carbon membranes. Macromolecules 2005;38(24):10042-9.

43. Kita H, Yoshino M, Tanaka K, Okamoto K. Gas permselectivity of carbonized polypyrrolone membrane. Chem Commun Jan. 1997;(11):1051-2.

44. Kim Y, Park H, Lee Y. Preparation and characterization of carbon molecular sieve membranes derived from BTDAeODA polyimide and their gas separation properties. J Memb Sci Jun. 2005;255(1-2):265-73.

45. Park H. Relationship between chemical structure of aromatic polyimides and gas permeation properties of their carbon molecular sieve membranes. J Memb Sci Feb. 2004;229(1-2):117-27.

46. Barsema J, Balster J, Jordan V, van der Vegt NF, Wessling M. Functionalized carbon molecular sieve membranes containing Ag-nanoclusters. J Memb Sci Jul. 2003;219(1-2):47-57.

47. Briceño K, Montane D, Garcia-Valls R, Iulianelli A, Basile A. Fabrication variables affecting the structure and properties of supported carbon molecular sieve membranes for hydrogen separation. J Memb Sci Oct. 2012;415-416:288-97. 
48. Anderson C, Pas S, Arora G, Kentish S, Hill A, Sandler S, et al. Effect of pyrolysis temperature and operating temperature on the performance of nanoporous carbon membranes. J Memb Sci Sep. 2008;322(1):19-27.

49. Song C, Wang T, Wang X, Qiu J, Cao Y. Preparation and gas separation properties of poly(furfuryl alcohol)-based C/CMS composite membranes. Sep Purif Technol Jan. 2008;58(3):412-8.

50. Lua AC, Su J. Effects of carbonisation on pore evolution and gas permeation properties of carbon membranes from Kapton ${ }^{\circledR}$ polyimide. Carbon N Y Nov. 2006;44(14):2964-72.

51. Suda H, Haraya K. Molecular sieving effect of carbonized kapton polyimide membrane. J Chem Soc Chem Commun Jan. 1995;(11):1179.

52. Campo MC, Magalhães FD, Mendes A. Carbon molecular sieve membranes from cellophane paper. J Memb Sci Mar. 2010;350(1-2):180-8.

53. Teixeira M, Campo MC, Pacheco Tanaka DA, Llosa Tanco MA, Magen C, Mendes A. Composite phenolic resin-based carbon molecular sieve membranes for gas separation. Carbon N Y Nov. 2011;49(13):4348-58.

54. Teixeira M, Campo M, Pacheco Tanaka DA, Llosa Tanco MA, Magen C, Mendes A. CarboneAl2O3eAg composite molecular sieve membranes for gas separation. Chem Eng Res Des Dec. 2012;90(12):2338-45.

55. Teixeira M, Rodrigues SC, Campo M, Pacheco Tanaka DA, Llosa Tanco MA, Madeira L, et al. Boehmite-phenolic resin carbon molecular sieve membranespermeation and adsorption studies. Chem Eng Res Des 2014;92:2668-80.

56. Rodrigues SC, Whitley R, Mendes A. Preparation and characterization of carbon molecular sieve membranes based on resorcinol-formaldehyde resin. J Memb Sci Jun. 2014;459:207-16.

57. Llosa Tanco MA, Pacheco Tanaka DA, Rodrigues SC, Texeira M, and Mendes A, "Composite-alumina-carbon molecular sieve membranes prepared from novolac resin and boehmite. Part I: preparation, characterization and gas permeation studies."

58. Parsley D, Ciora R, Flowers D, Laukaitaus J, Chen A, Liu P, et al. Field evaluation of carbon molecular sieve membranes for the separation and purification of hydrogen from coal- and biomass-derived syngas. J Memb Sci Jan. 2014;450:81-92.

59. Suda H, Haraya K. Gas permeation through micropores of carbon molecular sieve membranes derived from kapton polyimide. J Phys Chem B May 1997;101(20):3988-94.

60. Shiflett MB. Ultrasonic deposition of high-selectivity nanoporous carbon membranes. Science Sep. 1999;285(5435):1902-5.

61. Hosseini SS, Chung TS. Carbon membranes from blends of PBI and 
polyimides for $\mathrm{N}_{2} / \mathrm{CH}_{4}$ and $\mathrm{CO}_{2} / \mathrm{CH}_{4}$ separation and hydrogen purification. J Memb Sci Feb. 2009;328(1-2):174-85.

62. Braun. Polymer synthesis theory and practice fundamentals methods experiments. 4th ed. Springer; 2012.

63. Campo MC, Magalhães FD, Mendes A. Comparative study between a CMS membrane and a CMS adsorbent: Part I-morphology, adsorption equilibrium and kinetics. J Memb Sci Jan. 2010;346(1):15-25.

64. Sadezky A, Muckenhuber H, Grothe H, Niessner R, P@schl U. Raman microspectroscopy of soot and related carbonaceous materials: spectral analysis and structural information. Carbon N. Y Jul. 2005;43(8):1731-42.

65. Supova M, Svitilova J, Chlup Z, Cerny M, Weishauptova Z. Relation between mechanical properties and pyrolysis temperature of phenol formaldehyde resin for gas separation membranes 2012;56(1):40-9.

66. Evelyn AL, Ila D, Jenkins GM. RBS and Raman spectroscopy study of heattreatment effect on phenolformaldehyde resin. Nucl Instrum Methods Phys Res Sect B Beam Interact Mater Atoms Mar. 1994;85(1-4):861-3.

67. Kishore N, Sachan S, Rai KN, Kumar A. Synthesis and characterization of a nanofiltration carbon membrane derived from phenol e formaldehyde resin 2003;41:2961-72.

68. Xiao Y, Chng M, Chung T, Toriida M, Tamai S, Chen H, et al. Asymmetric structure and enhanced gas separation performance induced by in situ growth of silver nanoparticles in carbon membranes. Carbon N Y Feb. 2010;48(2):408-16. 69. Ottaway M. Use of thermogravimetry for proximate analysis of coals and cokes. Fuel Aug. 1982;61(8):713-6.

70. Gil A, Korili SA, Cherkashinin GY. Extension of the DubinineAstakhov equation for evaluating the micropore size distribution of a modified carbon molecular sieve. J Colloid Interface Sci Jul. 2003;262(2):603-7.

71. Nguyen C, Do DD. Adsorption of supercritical gases in porous media: determination of micropore size distribution. J Phys Chem B Aug. 1999;103(33):6900-8.

72. Nguyen C, Do DD, Haraya K, Wang K. The structural characterization of carbon molecular sieve membrane (CMSM) via gas adsorption. J Memb Sci Aug. 2003;220(1-2):177-82.

73. Rutherford SW, Do DD. Characterization of carbon molecular sieve 3A. Langmuir Sep. 2000;16(18):7245-54.

74. Breck DW. Zeolite molecular sieves, structure, chemistry and use. New York: John Wiley \& Sons Ltd.; 1974.

75. Campo MC, Lagorsse S, Magalhães FD, Mendes A. Comparative study between a CMS membrane and a CMS adsorbent: part II. Water vapor 
adsorption and surface chemistry. J Memb Sci Jan. 2010;346(1):26-36.

76. Rutherford SW. Modeling water adsorption in carbon micropores: study of water in carbon molecular sieves. Langmuir Jan. 2006;22(2):702-8.

77. Robeson LM. The upper bound revisited. J Memb Sci Jul. 2008;320(1-2):390400.

78. Tseng H-H, Itta AK. Modification of carbon molecular sieve membrane structure by self-assisted deposition carbon segment for gas separation. J Memb Sci Feb. 2012;389:223-33.

79. Zhou W, Yoshino M, Kita H, Okamoto K. "Preparation and gas permeation properties of carbon molecular sieve membranes based on sulfonated phenolic resin. J Memb Sci Jun. 2003;217(1-2):55-67.

80. Low BT, Xiao Y, Chung TS, Liu Y. Simultaneous occurrence of chemical grafting, cross-linking, and etching on the surface of polyimide membranes and their impact on H2/CO2 separation. Macromolecules Feb. 2008;41(4):1297-309.

81. Bux H, Liang F, Li Y, Cravillon J, Wiebcke M, Caro J. Zeolitic imidazolate framework membrane with molecular sieving properties by microwave-assisted solvothermal synthesis. J Am Chem Soc Nov. 2009;131(44):16000-1.

82. McCarthy MC, Varela-Guerrero V, V Barnett G, Jeong H-K. Synthesis of zeolitic imidazolate framework films and membranes with controlled microstructures. Langmuir Sep. 2010;26(18):14636-41.

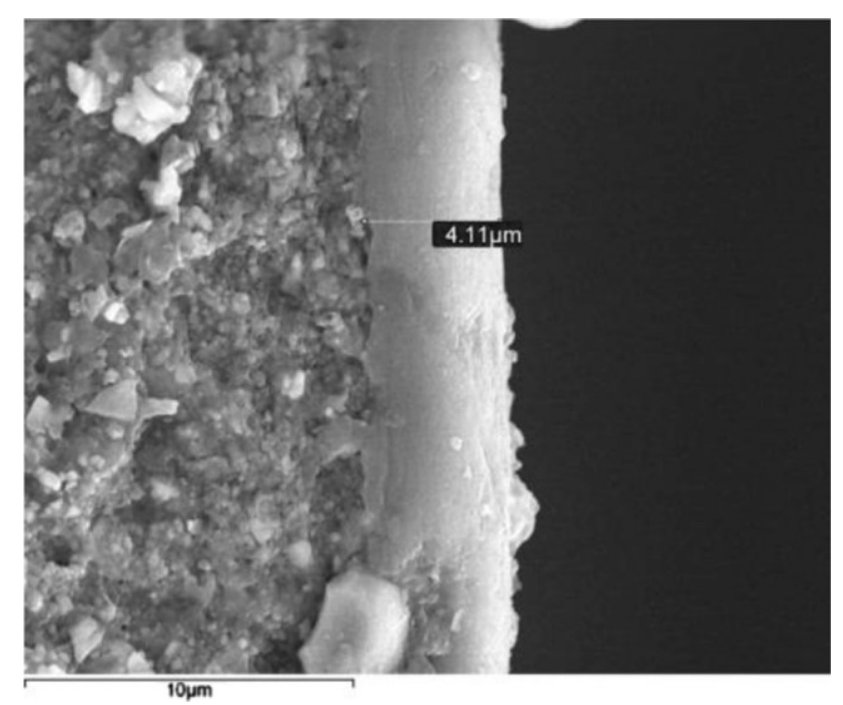

Fig. 1 - SEM photograph of the cross-section region of the c-CMSM supported on the alumina tube. 


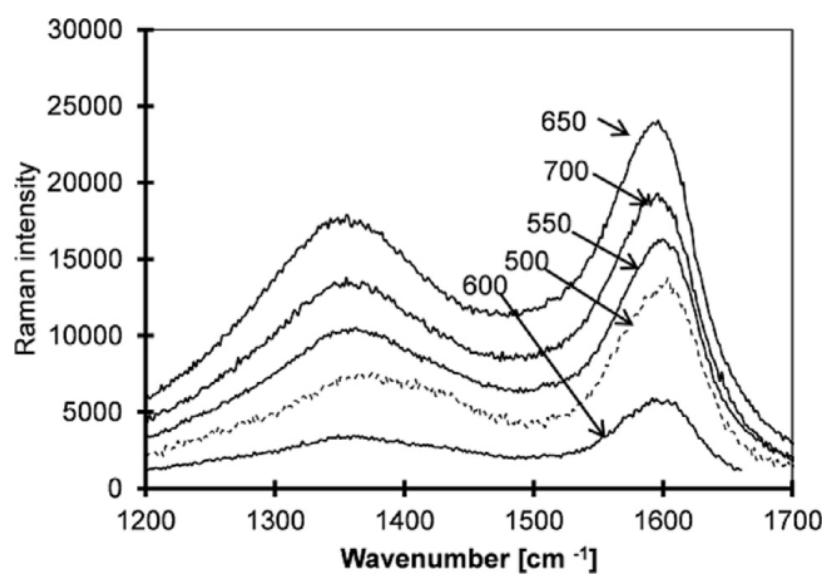

Fig. 2 -Raman spectra for c-CMSM carbonized at various end temperatures.

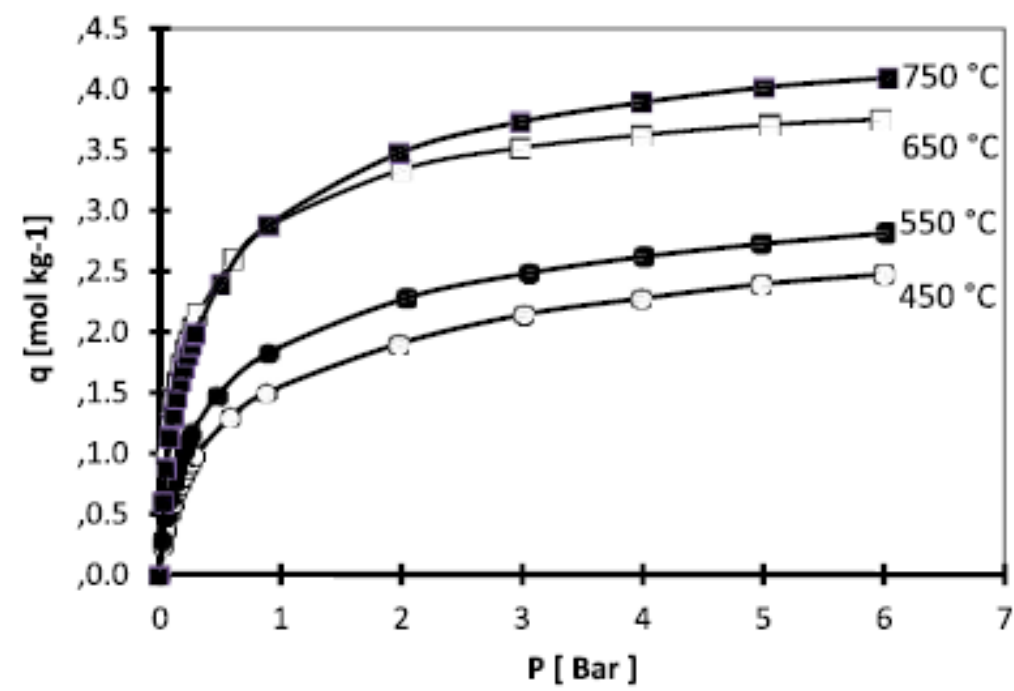

Fig. 3 - Adsorption equilibrium isotherm of $\mathrm{CO} 2$ at $\mathrm{O}^{{ }^{\circ} \mathrm{C}}$ on the $\mathrm{c}-\mathrm{CMSM}$ samples carbonized at $450,550,650$ and $750^{\circ} \mathrm{C}$

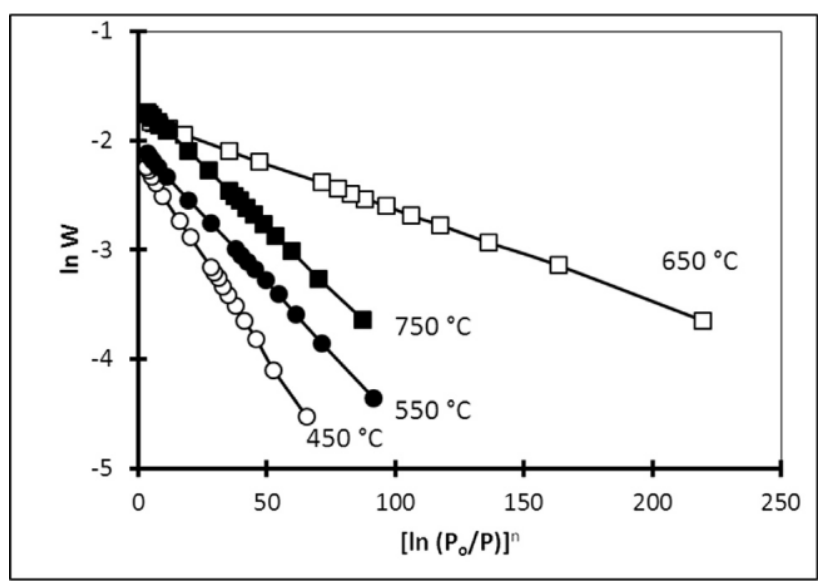

Fig. 4 - Carbon dioxide characteristic curve for the c-CMSM carbonized at $450,550,650$ and $750^{\circ} \mathrm{C}$. 


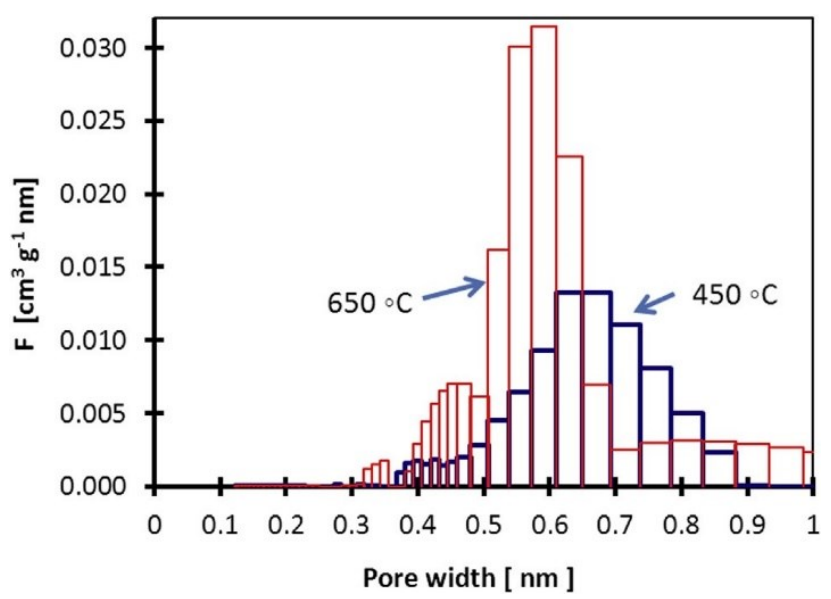

Fig. 5 - Micropore size distribution of c-CMSM carbonized at 450 and $650{ }^{\circ} \mathrm{C}$.

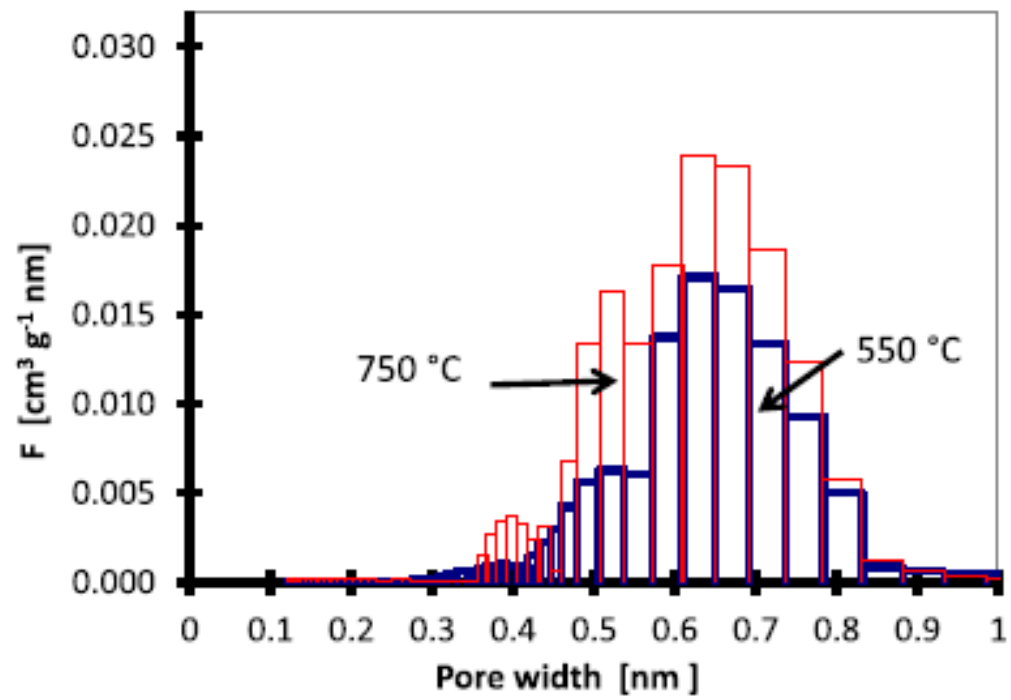

Fig. 6 - Micropore size distribution of c-CMSM carbonized at 550 and $750{ }^{\circ} \mathrm{C}$. 


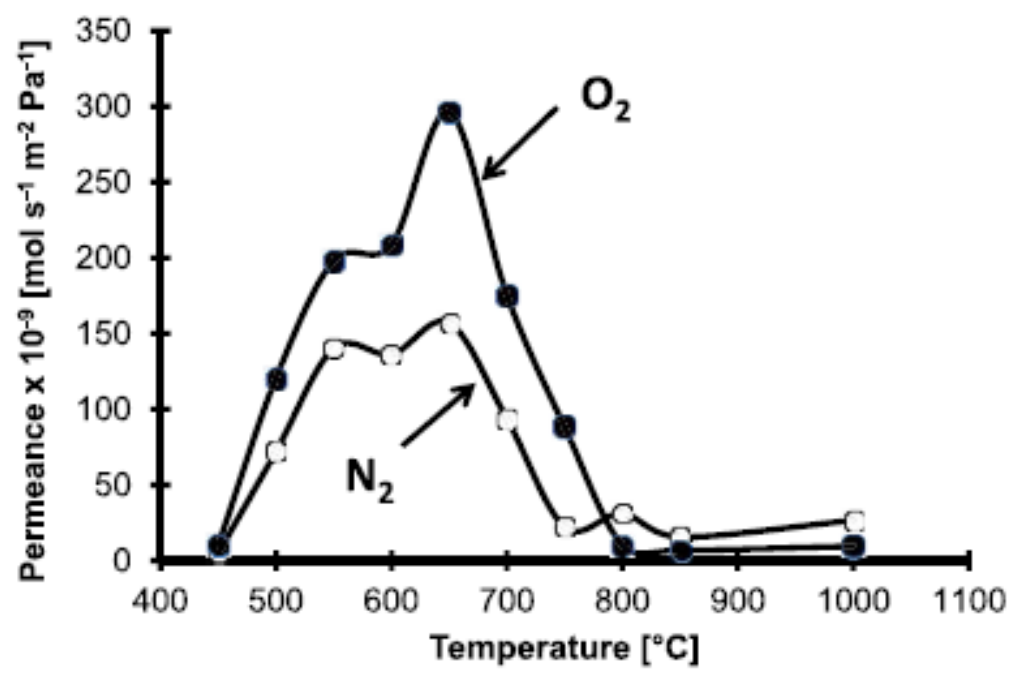

Fig. 7 - c-CMSM permeance to $\mathrm{N} 2$ and $\mathrm{O} 2$ as a function of carbonization end temperature

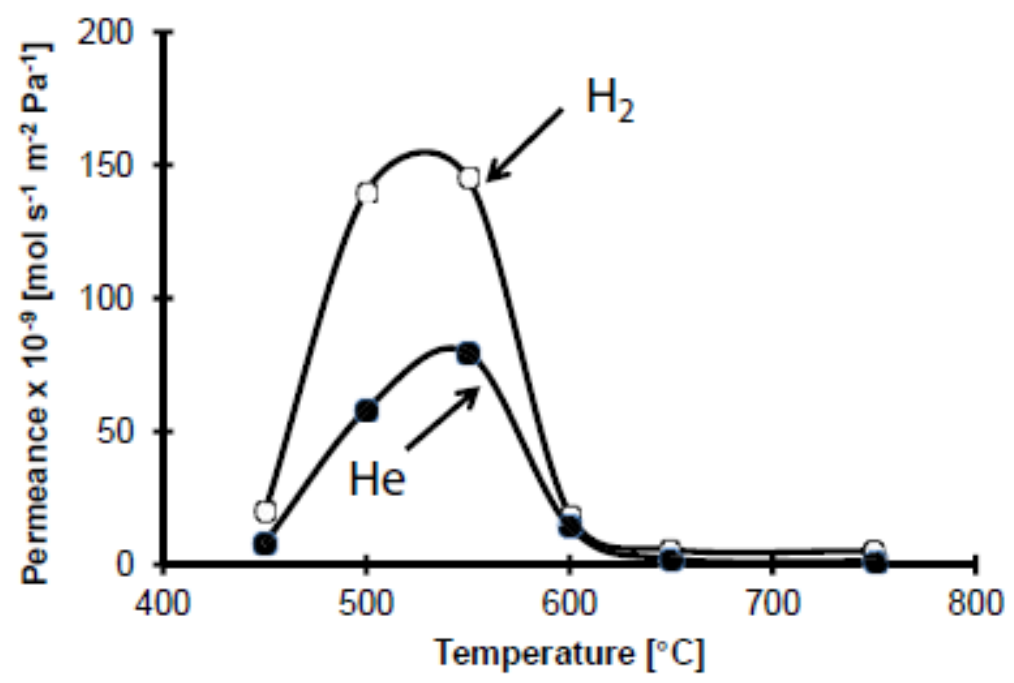

Fig. 8 - Permeance of c-CMSM carbonized at various temperatures and after 1 day aging to $\mathrm{He}$ and $\mathrm{H} 2$ (lines were added for readability). 


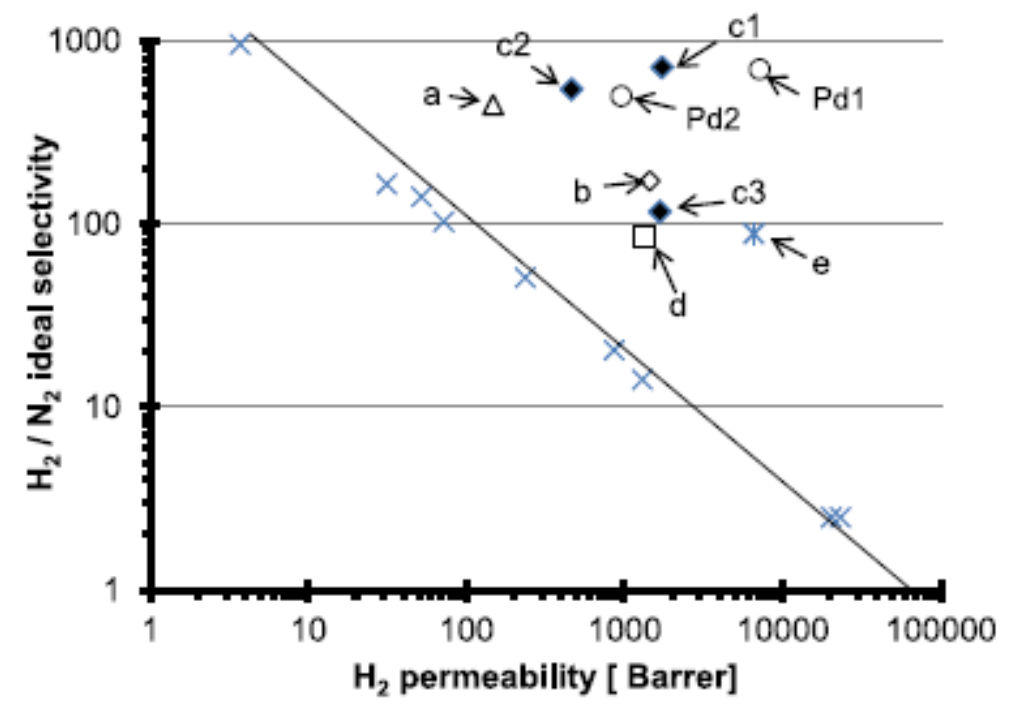

Fig. 9 - Robeson upper bound plot for H2/N2 for: (a) Campo [52], (b) Tseng [78], (c1) This work (CMSM550-1d); (c2) This work (CMSM600-5m); (c3) This work (CMSM500-1d); (d) Hosseini [61], (e) Kita [79](Pd1) Pd pore filled membranes at $100{ }^{\circ} \mathrm{C}$; and $(\mathrm{Pd} 2) \mathrm{Pd}$ pore filled membranes at $50{ }^{\circ} \mathrm{C}$ [12].

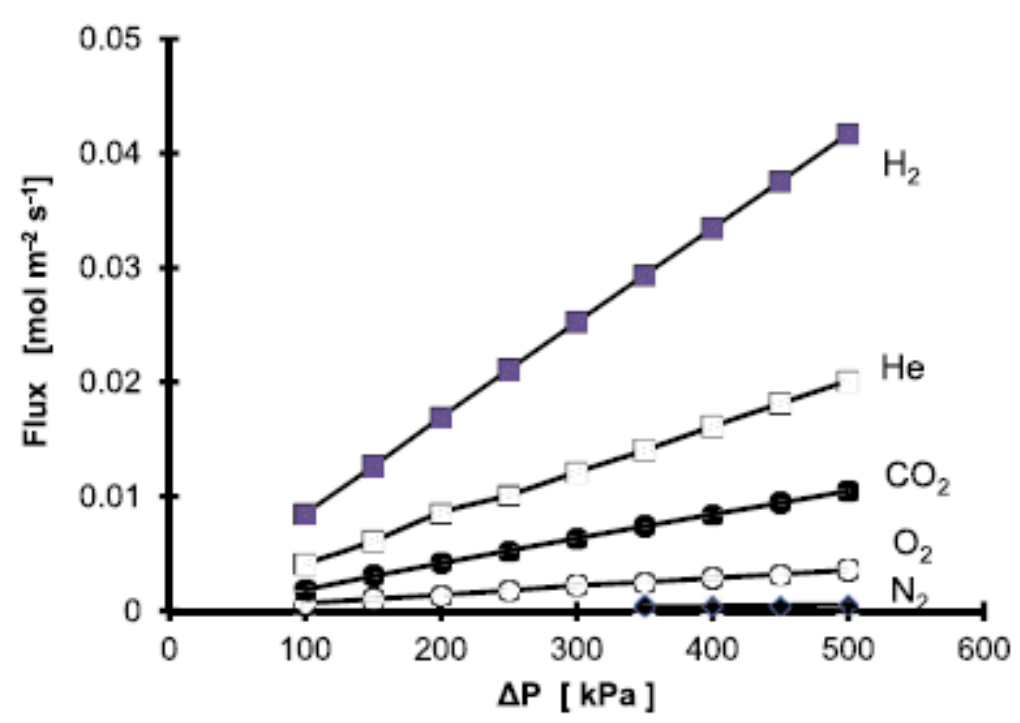

Fig. 10 - Permeation fluxes through membrane c-CMSM- 500-5m (activated at $200{ }^{\circ} \mathrm{C}$ ) as a function of the relative feed pressure at $60{ }^{\circ} \mathrm{C}$ and for different single gases 


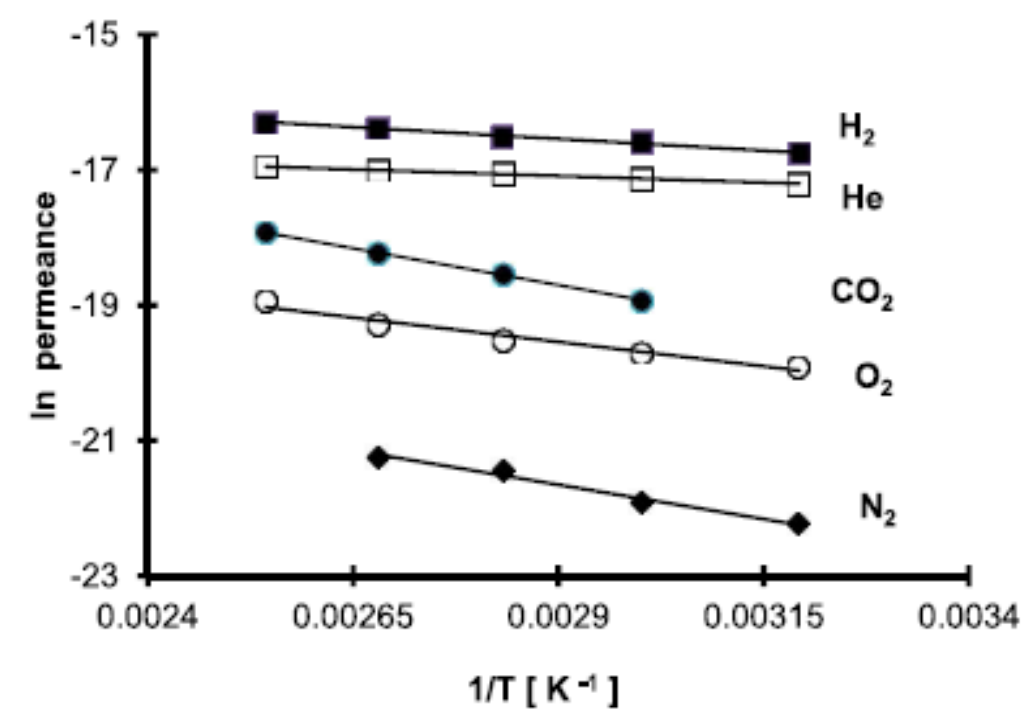

Fig. 11 - Arrhenius type plot of permeance for various gases measured at room temperature of aged membrane c- CMSM-500-5m activated at $120{ }^{\circ} \mathrm{C}$.

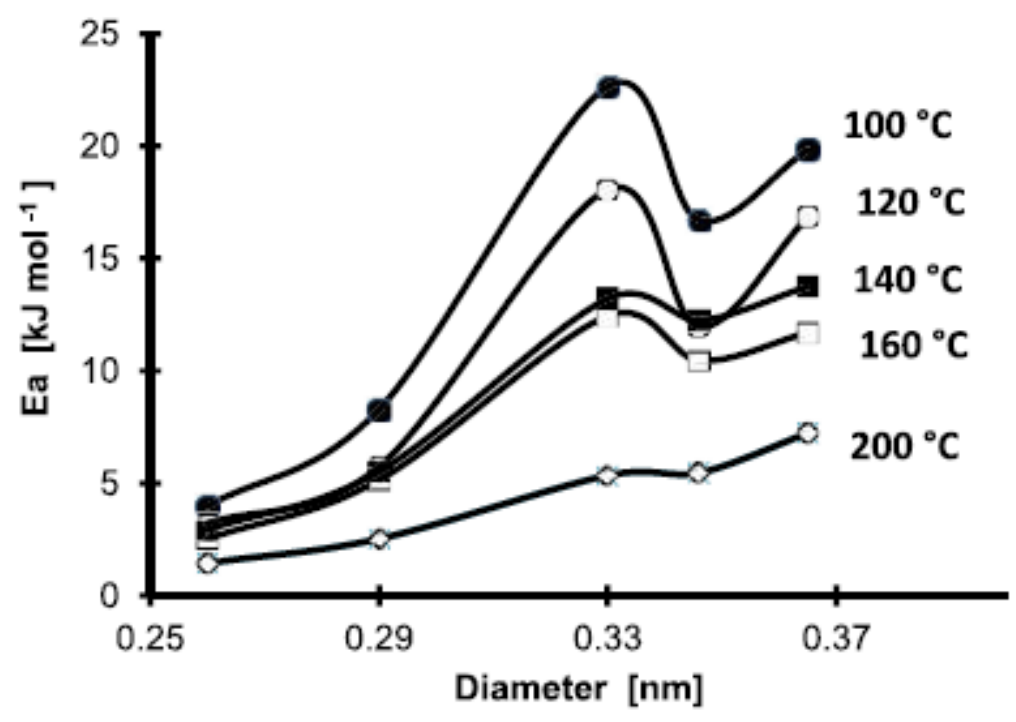

Fig. 12 - Activation energy in c-CMSM-500 membrane activated from 100 to $200{ }^{\circ} \mathrm{C}$, for: $\mathrm{N} 2(0.365 \mathrm{~nm}), \mathrm{O} 2(0.346 \mathrm{~nm}), \mathrm{CO} 2(0.33 \mathrm{~nm}), \mathrm{H} 2(0.290 \mathrm{~nm})$ and $\mathrm{He}(0.260 \mathrm{~nm})$. The values correspond to the average of permeation data performed at different temperatures from $40{ }^{\circ} \mathrm{C}$ to $120{ }^{\circ} \mathrm{C}$ (lines were added for readability). 


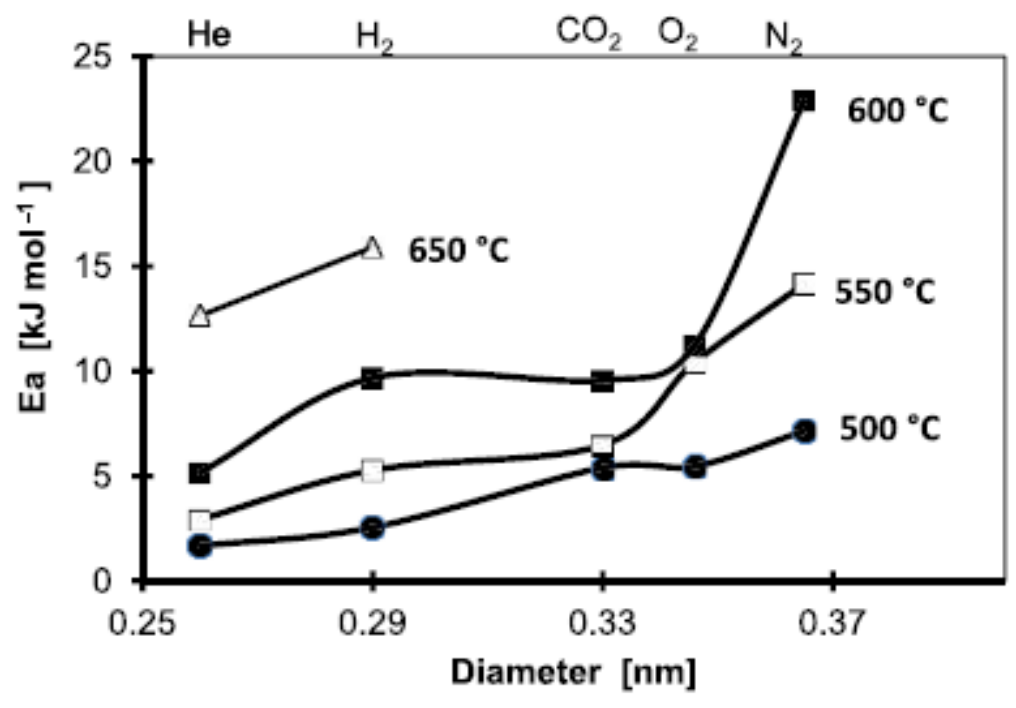

25

${ }_{20}$ Fig. 13 - Activation energy for permeating species N2, O2, CO2, H2 and He in c-CMSM500-5m, c-CMSM550-5m, c- CMSM600-5m and c-CMSM650-5m membranes activated at $200{ }^{\circ} \mathrm{C}$ under $\mathrm{N} 2$ (lines were added for readability)

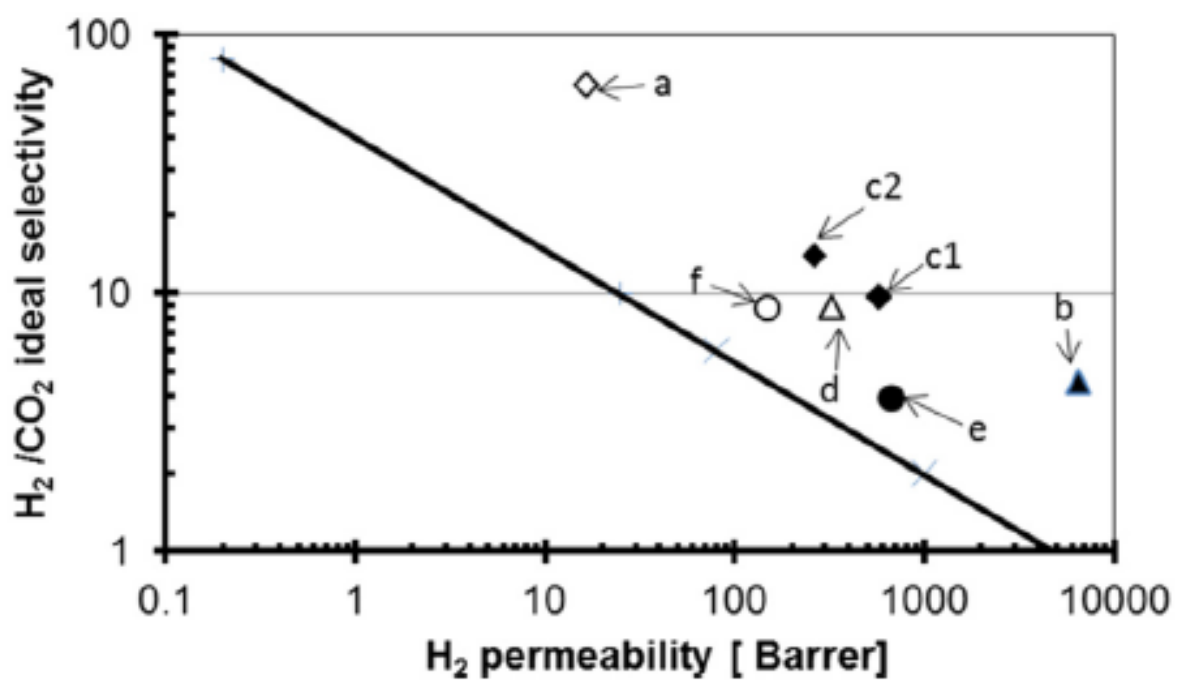

Fig. 14 e Robeson's revised upper bound for $\mathrm{H}_{2} / \mathrm{CO} 2$ and values from the literature and from this work for carbon molecular sieve membranes: (a) Low [80], (b) Bux [81], (c1) this work (CMSM600-200-80), (c2) this work (CMSM600200-30), (d) Hosseini [61], (e) Mc Carthy [82], (f) Campo [52]. 
Table $1-\mathrm{H}_{2}$ permeability and $\mathrm{H}_{2} / \mathrm{N}_{2}$ permselectivities for carbon molecular sieve membranes.

\begin{tabular}{|c|c|c|c|c|}
\hline Precursor & Pyrolysis conditions & $\mathrm{H}_{2}$ permeance barrer & Selectivity $\mathrm{H}_{2} / \mathrm{N}_{2}$ & Reference \\
\hline \multirow[t]{3}{*}{ Kapton } & $600^{\circ} \mathrm{C}, 120 \mathrm{~min}$ & 1600 & 19.6 & Suda \& Haraya [59] \\
\hline & $800^{\circ} \mathrm{C}, 120 \mathrm{~min}$ & 669 & 220 & \\
\hline & $1000^{\circ} \mathrm{C}, 120 \mathrm{~min}$ & 59.4 & 1450 & \\
\hline \multirow{3}{*}{ Polyfurfurylalcohol } & $300^{\circ} \mathrm{C}, 120 \mathrm{~min}$ & 0.83 & 175 & Shiflett [60] \\
\hline & $450^{\circ} \mathrm{C}, 120 \mathrm{~min}$ & 3.63 & 331 & \\
\hline & $600^{\circ} \mathrm{C}, 120 \mathrm{~min}$ & 8.14 & 29.8 & \\
\hline \multirow[t]{3}{*}{ Polypyrrolone } & $500{ }^{\circ} \mathrm{C}, 60 \mathrm{~min}$ & 6580 & 88.6 & Kita et al., [43] \\
\hline & $700^{\circ} \mathrm{C}, 60 \mathrm{~min}$ & 1720 & 267.5 & \\
\hline & $800^{\circ} \mathrm{C}, 60 \mathrm{~min}$ & 25.4 & $\begin{array}{l}1080 . \\
9\end{array}$ & \\
\hline PBI & & 0.60 & 125.1 & Hosseini [61] \\
\hline Matrimid & & 27.2 & 97.0 & \\
\hline PBI/Matrimid(50/50 wt\%) & $600^{\circ} \mathrm{C}$ & 1337 & 85.1 & \\
\hline PBI/Matrimid(50/50 wt\%) & $700^{\circ} \mathrm{C}$ & 940.3 & 149.3 & \\
\hline PBI/Matrimid(50/50 wt\%) & $800^{\circ} \mathrm{C}$ & 324 & 257.1 & \\
\hline Matrimid & $650^{\circ} \mathrm{C}$ & 323 & 4.41 & Briceño et al. [47] \\
\hline CMSM from cellophane & $550^{\circ} \mathrm{C}, \mathrm{N}_{2}$ & 168.1 & 390 & Campo et al. [52] \\
\hline CMSM from Resol-phenolic resin & $550^{\circ} \mathrm{C}, \mathrm{N}_{2}$ & 2047 & 65.6 & Texeira et al. [55] \\
\hline CMSM from Resorcinol-formaldehyde resin & $550^{\circ} \mathrm{C}, \mathrm{N}_{2}$ & 301 & $>586$ & Rodrigues et al. [56] \\
\hline
\end{tabular}


Table 2 - Structural parameters of the C-CMSM

carbonized at different temperatures.

\begin{tabular}{lcc} 
Sample & $I_{D} / I_{G}$ & $f(\%)$ \\
\hline CMSM-500 & 0.536 & 34.9 \\
CMSM-550 & 0.636 & 38.9 \\
CMSM-600 & 0.658 & 40.1 \\
CMSM-650 & 0.764 & 43.3 \\
CMSM-700 & 0.768 & 43.4
\end{tabular}

Table 3 - Structural parameters determined from the DA

fit for the C-CMSM carbonized at different temperatures.

\begin{tabular}{lccc}
$\begin{array}{l}\text { Carbonizing end temperature } \\
{ }^{\circ} \mathrm{C}\end{array}$ & $n$ & $\begin{array}{c}\mathrm{W}_{0} \\
\mathrm{~cm}^{-3} \mathrm{~g}^{-1}\end{array}$ & $\begin{array}{c}E_{0} \\
\mathrm{~kJ} \mathrm{~mol}^{-1}\end{array}$ \\
\hline 450 & 2.14 & 0.119 & 11.6 \\
550 & 2.30 & 0.131 & 12.2 \\
650 & 2.75 & 0.167 & 14.1 \\
750 & 2.29 & 0.192 & 11.8
\end{tabular}


Table 4 - c-CMSM permeances at room temperature to $\mathbf{O}_{2}$, and $\mathrm{N}_{\mathbf{2}}$ and ideal permselectivities after carbonization (fresh membranes) at various temperatures.

\begin{tabular}{|c|c|c|c|c|c|c|c|c|c|}
\hline \multirow{2}{*}{\multicolumn{2}{|c|}{$\begin{array}{l}\text { Temp } \\
{ }^{\circ} \mathrm{C}\end{array}$}} & \multicolumn{3}{|c|}{$\mathrm{mol} \mathrm{m}^{-2} \mathrm{~s}^{-1} \mathrm{~Pa}^{-1} \times 10^{-9}$} & \multirow{2}{*}{\multicolumn{2}{|c|}{$\begin{array}{c}\text { Temp } \\
{ }^{\circ} \mathrm{C}\end{array}$}} & \multicolumn{3}{|c|}{$\mathrm{mol} \mathrm{m}{ }^{-2} \mathrm{~s}^{-1} \mathrm{~Pa}^{-1} \times 10^{-9}$} \\
\hline & & $\mathrm{N}_{2}$ & $\mathrm{O}_{2}$ & $\mathrm{O}_{2} / \mathrm{N}_{2}$ & & & $\mathrm{~N}_{2}$ & $\mathrm{O}_{2}$ & $\mathrm{O}_{2} / \mathrm{N}_{2}$ \\
\hline CMSM450-F & 450 & 4.9 & 10 & 2.1 & CMSM700-F & 700 & 94 & 175 & 1.9 \\
\hline CMSM500-F & 500 & 72 & 121 & 1.7 & CMSM750-F & 750 & 22 & 88 & 4.0 \\
\hline CMSM550-F & 550 & 140 & 198 & 1.4 & CMSM800-F & 800 & 31 & 10 & 0.3 \\
\hline CMSM600-F & 600 & 136 & 209 & 1.5 & CMSM850-F & 850 & 16 & 6.8 & 0.4 \\
\hline CMSM650-F & 650 & 157 & 296 & 1.9 & CMSM1000-F & 1000 & 27 & 9.5 & 0.4 \\
\hline
\end{tabular}

Table 5 - $\mathrm{c}$-CMSM permeance to $\mathrm{N}_{2}, \mathrm{O}_{2}, \mathrm{H}_{2}$ and $\mathrm{He}$ at $30^{\circ} \mathrm{C}$ and ideal permselectivities for c-CMSM carbonized at different temperatures after 1 day aging.

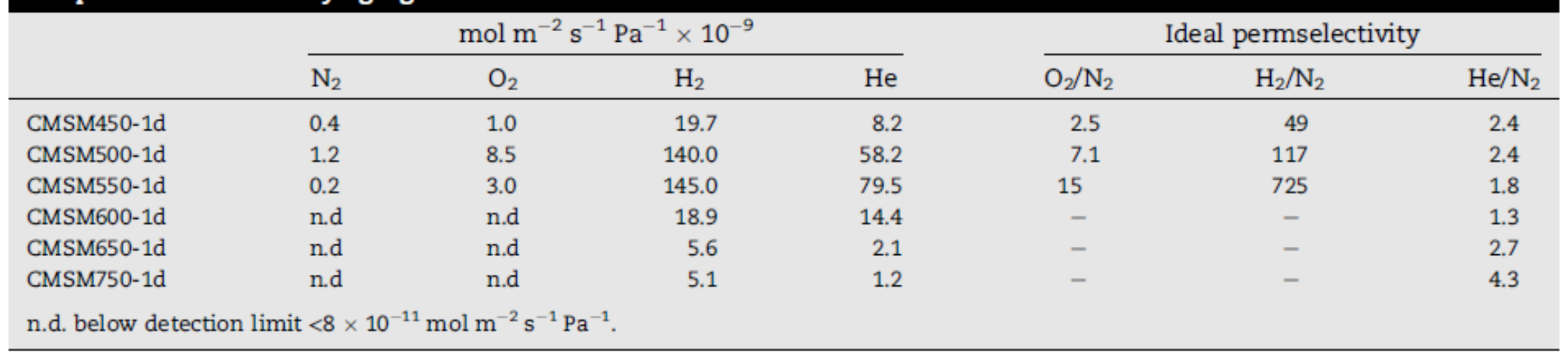


Table 6 - Activation energy for permeating species $\mathrm{N}_{2}, \mathrm{O}_{2}, \mathrm{CO}_{2}, \mathrm{H}_{2}$ and $\mathrm{He}$ at $30^{\circ} \mathrm{C}$ in c-CMSM500-5m membrane after 20 weeks of aging and upon activation at various temperatures.

\begin{tabular}{|c|c|c|c|c|c|c|c|}
\hline \multirow{2}{*}{\multicolumn{2}{|c|}{$\begin{array}{c}\text { Diameter } \\
(\mathrm{nm})\end{array}$}} & \multicolumn{6}{|c|}{$E_{a}\left(\mathrm{~kJ} \mathrm{~mol}^{-1}\right)^{\mathrm{a}}$} \\
\hline & & $100^{\circ} \mathrm{C}$ & $120^{\circ} \mathrm{C}$ & $140^{\circ} \mathrm{C}$ & $160^{\circ} \mathrm{C}$ & $180^{\circ} \mathrm{C}$ & $200^{\circ} \mathrm{C}$ \\
\hline $\mathrm{N}_{2}$ & 0.365 & 19.8 & 16.8 & 11.7 & 13.8 & 7.2 & 7.2 \\
\hline $\mathrm{O}_{2}$ & 0.346 & 16.7 & 12.0 & 10.5 & 12.3 & 5.5 & 5.5 \\
\hline $\mathrm{CO}_{2}$ & 0.335 & 22.7 & 18.1 & 12.4 & 13.2 & 5.4 & 5.4 \\
\hline $\mathrm{H}_{2}$ & 0.290 & 8.3 & 5.7 & 5.1 & 5.5 & 2.5 & 2.5 \\
\hline $\mathrm{He}$ & 0.260 & 4.0 & 3.2 & 2.5 & 2.9 & 1.5 & 1.5 \\
\hline
\end{tabular}

Table 7 - Activation energy for permeating species $\mathrm{N}_{\mathbf{2}}, \mathbf{O}_{\mathbf{2}}$, $\mathrm{CO}_{2}, \mathrm{H}_{2}$ and $\mathrm{He}$ at $40-120^{\circ} \mathrm{C}$ in c-CMSM500-5m, c-

CMSM550-5m, c-CMSM600-5m and c-CMSM650-5m membranes, activated at $200{ }^{\circ} \mathrm{C}$ under $\mathrm{N}_{2}$.

\begin{tabular}{lccccc} 
& \multirow{2}{*}{$\begin{array}{c}\text { Diameter } \\
(\mathrm{nm})\end{array}$} & $500^{\circ} \mathrm{C}$ & $550^{\circ} \mathrm{C}$ & $600^{\circ} \mathrm{C}$ & $650{ }^{\circ} \mathrm{C}$ \\
\cline { 3 - 6 } & & 7.1 & 14.1 & 22.9 & n.d. \\
\hline $\mathrm{N}_{2}$ & 0.365 & 5.5 & 10.4 & 11.2 & n.d. \\
$\mathrm{O}_{2}$ & 0.346 & 5.4 & 6.5 & 9.6 & n.d. \\
$\mathrm{CO}_{2}$ & 0.335 & 2.6 & 5.3 & 6.7 & 15.9 \\
$\mathrm{H}_{2}$ & 0.290 & 1.7 & 2.9 & 5.2 & 12.6 \\
$\mathrm{He}$ & 0.260 & & & \\
\hline \multicolumn{5}{l}{ n.d. (permeance below the detection limits). } \\
${ }^{\mathrm{a}} \mathrm{E}_{a}$ calculated using eq. (4).
\end{tabular}

